ROBERT KOWALIK

JAROSŁAW GAWDZIK

Kielce University of Technology

ALICJA GAWDZIK

University of Opole

BARBARA GAWDZIK

The Jan Kochanowski University in Kielce

e-mail: robert2099290@gmail.com
Manuscript submitted 2018.11.20 - revised 2019.01.04, initially accepted for publication 2019.02.10, published in June 2019

\title{
INNOVATIVE SEQUENTIAL BATCH REACTOR SOLUTIONS FOR WASTEWATER TREATMENT
}

\section{INNOWACYJNE ROZWIAZANIA SEKWENCYJNYCH REAKTORÓW PORCJOWYCH STOSOWANE W OCZYSZCZANIU ŚCIEKÓW}

DOI: $10.30540 /$ sae-2019-011

\begin{abstract}
Sequential Biological Reactors (SBR) are widely used for wastewater treatment, which is becoming increasingly contaminated with new and more complex substances. Therefore, it is beneficial to include various configurations and operational modifications in order to purify wastewater more effectively. The paper presents a basic description of the SBR process and its modifications, which lead to better removal of the resulting contaminants. The Cyclic Activated Sludge System (CASS) was characterized as one of the most popular sequential reactor (SBR) processes used for the treatment of municipal wastewater and sewage emissions from a variety of industries, including refineries and petrochemicals. Another example presented in this paper is the Unitank biological wastewater treatment system, which combines the advantages of a traditional process with activated sludge and an SBR reactor. The last example of SBR technology modification, presented in the article, is ICEAS (Intermediate Cycle Extended Aeration System) process, which processes continuous sewage inflow. The variable inlet is supported by a distribution box which distributes the flow evenly over all the tanks in order to avoid overloading a single tank. In each case, the benefits of using a given modification are presented.
\end{abstract}

Keywords: wastewater treatment, modern wastewater treatment methods, aerobic reactors, SBR, CASS, UNITANK, ICEAS

\section{Streszczenie}

Sekwencyjne biologiczne reaktory (SBR) sa szeroko wykorzystywane do oczyszczania ścieków, które obecnie staja się zanieczyszczone coraz to nowymi i bardziej złożonymi substancjami. Korzystne zatem staje się włączenie różnego rodzaju rozszerzajacych się konfiguracji oraz modyfikacji operacyjnych, aby efektywniej oczyszczać ścieki. W pracy przedstawiono podstawowy opis procesu SBR oraz jego modyfikacji, które prowadza do lepszego usuwania powstajacych zanieczyszczeń. Scharakteryzowano cykliczny system osadów czynnych (CASS), który jest jednym z najpopularniejszych procesów reaktorów sekwencyjnych (SBR) stosowanych do oczyszczania ścieków komunalnych oraz ścieków $z$ różnych branż, w tym rafinerii i zakładów petrochemicznych. Kolejnym przykładem przedstawionym w pracy jest biologiczny system oczyszczania ścieków Unitank, który taczy w sobie zalety tradycyjnego procesu z osadem czynnym oraz reaktora SBR. Ostatnim przykładem modyfikacji technologii SBR, jaki przedstawiono w artykule, jest proces ICEAS (Intermediate Cycle Extended Aeration System). W reaktorach ICEAS zmienny doplyw jest obstugiwany przez skrzynke rozdzielająca, która rozdziela przeplyw równomiernie na wszystkie zbiorniki tak, aby uniknąć przeciązenia pojedynczego zbiornika. W każdym przypadku przedstawiono korzyści płynące z wykorzystania danej modyfikacji.

Słowa kluczowe: oczyszczanie ścieków, nowoczesne metody oczyszczania ścieków, reaktory tlenowe, SBR, CASS, UNITANK, ICEAS 


\section{INTRODUCTION}

As demands on the quality of wastewater discharged into the environment increase, the continuous flow biological treatment of wastewater poses a major challenge. The SBR (Sequencing Batch Reactor) batch sequencing technology is a modification of a popular ASP (Activated Sludge Process) process [1]. This conversion of the continuous sludgebased treatment process into a batch process as in SBR improves the flexibility and control of the processes involved to meet the requirements for discharging wastewater to the collector. Modern development of wastewater treatment with activated sludge in portioning systems was achieved through the research of Irvine and his co-workers in the sixties of the twentieth century. Irvine first used the name sequential biological reactor for a single-tank reactor, which he designed in 1969 for large-scale industrial wastewater treatment at Corpus Christi, Texas [2]. In the first years of its operation, SBR was mainly used in municipal domestic sewage treatment plants. Due to the flexibility of design and better process control, which can be achieved by modern technology, the use of the SBR process was not limited to urban wastewater treatment, but was also widely used in the biological treatment of industrial wastewater containing organic compounds which are difficult to treat [3]. As the SBR process can be effectively automated, it saves more than $60 \%$ of the operating costs required for a conventional activated sludge process and is able to achieve high wastewater quality with a short aeration time [4]. In highly populated countries such as India and Europe, SBR is considered a BAT technology due to its low space and labour requirements. The SBR process is often preferred over the Continuous Flow Process (CFP) due to reduced energy consumption, nutrient removal and control of filamentous bacteria [1]. For these reasons, the SBR process has become more and more popular in recent years. Over the past few years, SBR has undergone several minor and major modifications to effectively treat the rapidly growing number of new pollutants in wastewater. This article provides an insight into the technology as well as an overview of the latest developments in the design and application of SBR technology.

\section{WPROWADZENIE}

W miarę jak rosną wymagania w zakresie jakości ścieków odprowadzonych do środowiska, biologiczne procesy oczyszczania ścieków muszą być stale udoskonalane. Technologia sekwencjonowania wsadowego reaktora SBR (Sequencing Batch Reactor) jest modyfikacją popularnego procesu z osadem czynnym ASP (Activated Sludge Process) [1]. Taka konwersja ciągłego charakteru procesu oczyszczania opartego na osadzie czynnym na proces wsadowy, jak w SBR, poprawia elastyczność oraz kontrolę zachodzących procesów, tak aby osiągnąć wymagania w zakresie odprowadzania ścieków do odbiornika. Współczesny rozwój oczyszczania ścieków osadem czynnym w systemach porcjowych dokonał się dzięki badaniom Irvine'a i jego współpracowników w latach sześćdziesiątych XX wieku. Irvine po raz pierwszy użył nazwy sekwencyjny reaktor biologiczny dla jednozbiornikowego reaktora, który zaprojektował w 1969 roku do oczyszczania na dużą skalę ścieków przemysłowych w Corpus Christi w Teksasie [2]. W pierwszych latach technologia SBR była wykorzystywana głównie w gminnych oczyszczalniach ścieków bytowo-gospodarczych. Ze względu na elastyczność projektowania i lepszą kontrolę, którą można osiągnąć dzięki nowoczesnej technologii, zastosowanie procesu SBR nie ograniczyło się tylko do oczyszczania ścieków komunalnych, ale znalazło również szerokie zastosowanie w biologicznym oczyszczaniu ścieków przemysłowych zawierających trudne do oczyszczenia związki organiczne [3]. Ponieważ proces SBR można skutecznie zautomatyzować, pozwala on zaoszczędzić ponad $60 \%$ kosztów operacyjnych wymaganych w przypad$\mathrm{ku}$ konwencjonalnego procesu z osadem czynnym, a także można osiągnąć wysoką jakość ścieków przy krótkim czasie napowietrzania [4]. W gęsto zaludnionych krajach, takich jak np. Indie, oraz w Europie SBR jest uważany za technologię BAT ze względu na niskie zapotrzebowanie na powierzchnię oraz siłę roboczą. Proces SBR ze względu na zmniejszenie zużycia energii, usuwanie składników odżywczych i kontrolę bakterii nitkowatych jest częściej preferowany niż proces ciągłego przepływu [1]. Z tych powodów proces SBR zyskuje w ostatnich latach na popularności. Technologia SBR w ciągu ostatnich kilku lat przechodziła kilka, zarówno drobnych, jak i poważnych modyfikacji, aby skutecznie oczyszczać gwałtownie rosnącą liczbę nowych zanieczyszczeń w ściekach. Ten artykuł przedstawia wgląd w technologię, jak również przegląd najnowszych postępów w projektowaniu i stosowaniu technologii SBR. 


\section{SBR PROCESS}

SBR systems should therefore be understood as biological processes of wastewater treatment, whose common feature is:

- application of the activated sludge process to biological wastewater treatment,

- the process of biological treatment and separation of the activated sludge from the treated wastewater takes place in the same tank,

- the water level in the tank is raised by the supply of wastewater for treatment,

- the treated wastewater is discharged from the tank in portions [4].

Depending on the scale of operations, the SBR system, with its variants and hybrids, may include single-tank or multi-tank reactors, each with five basic operating phases [1]. The duration of each phase in the tank can be adapted to different treatment requirements, such as low COD in the wastewater, biological removal of nutrients, etc. Figure 1 schematically shows the different operating modes of the SBR system. The number of phases also provides information on a number of alternative solutions that can be applied at each of the individual stages in order to achieve the assumed purification objectives [4].

During the filling phase, the tank receives wastewater that comes into contact with the active biomass left in the reactor at the end of the previous cycle. Depending on the characteristics of the wastewater, the target organic matter and the biological removal of nutrients, three variants can be used individually or in combination: static filling, mixing and aeration. During static filling, the incoming wastewater is added without mixing to the biomass already present in the SBR, which is almost similar to the batch flow situation, creating a high nutrient-microbial ratio $(\mathrm{F} / \mathrm{M})$, similar to the selector chamber used in the ASP, stimulating the growth of floccogenic bacteria by suppressing those that provide good sedimentation properties [3].

\section{PRZEBIEG PROCESU SBR}

Jako systemy SBR należy zatem rozumieć procesy biologiczne oczyszczania ścieków, których wspólnymi cechami są:

- zastosowanie procesu osadu czynnego do biologicznego oczyszczania ścieków,

- przebieg procesów biologicznego oczyszczania i oddzielanie osadu czynnego od oczyszczonych ścieków następuje w tym samym zbiorniku,

- zwierciadło wody w zbiorniku podnosi się na skutek doprowadzania przeznaczonych do oczyszczania ścieków,

- oczyszczone ścieki odprowadzane są ze zbiornika porcjowo [4].

W zależności od skali działania system SBR, wraz z jego wariantami i hybrydami, może obejmować reaktory jedno- lub wielozbiornikowe, z których każdy posiada pięć podstawowych faz pracy [1]. Czas trwania każdej fazy w zbiorniku może być dostosowany do różnych potrzeb oczyszczania, takich jak niskie ChZT w ściekach, biologiczne usuwanie składników pokarmowych itp. Rysunek 1 schematycznie przedstawia różne tryby pracy systemu SBR. Liczba faz informuje również o kilku alternatywnych rozwiązaniach możliwych do zastosowania na każdym z poszczególnych etapów, tak aby osiągnąć założone cele oczyszczania [4].

Podczas fazy napełniania zbiornik odbiera surowe ścieki, które kontaktują się z aktywną biomasą pozostawioną w reaktorze pod koniec poprzedniego cyklu. W zależności od charakterystyki ścieków, docelowej substancji organicznej i biologicznego usuwania składników pokarmowych można stosować pojedynczo lub łącznie trzy warianty: napełnienie statyczne, mieszanie i napowietrzanie. Podczas napełnienia statycznego wpływające ścieki są dodawane bez mieszania do biomasy obecnej już w reaktorach, co przypomina prawie sytuację przepływu wsadowego, czego efektem jest wysoki stosunek pożywki do mikroorganizmów (F/M), podobnie jak w przypadku komory selektora używanej w metodach osadu czynnego, promując wzrost bakterii flokogennych poprzez wytłumienie tych, które zapewniają dobre właściwości sedymentacji osadu [3]. 


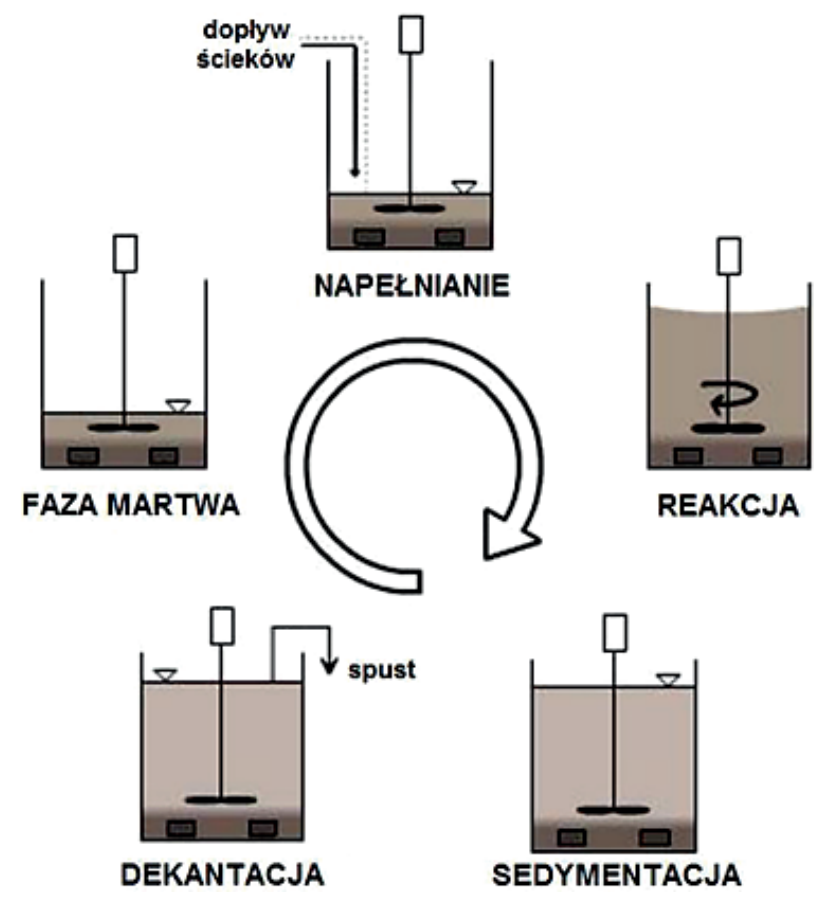

Reaction phase - in this phase, aerobic and anaerobic conditions are alternately generated. The load on the activated sludge increases with the flow of wastewater.

Sedimentation phase - operation of the aeration and mixing device is stopped. The process of sludge sedimentation and wastewater clarification begins.

Decantation phase - once the sedimentation process is complete, the activated sludge accumulates in the bottom layer, revealing the clarified wastewater layer. Pumped or static decanting of treated wastewater takes place. Excess sludge is removed at the end of the decantation period.

The dead phase - this is the time between decantation and filling. This phase is often necessary when several reactors are operating in parallel. At this stage, depending on the exploitation strategy, biomass mixing may be used to condition the reactive content [3].

\section{DIFFERENT SBR TECHNOLOGY OPTIONS}

\subsection{Cyclic Active Sediment System (CASS)}

The Cyclic Activated Sludge System (CASS) is one of the most popular sequencing reactor (SBR) processes used to treat municipal wastewater and wastewater from various industries, including refineries and petrochemical plants [5].

Compared to the traditional activated sludge process, it offers a number of operational and performance advantages. The CASS SBR process fulfils all the
Fig. 1. Concept of operation of the SBR reactor [4] Rys. 1. Koncepcja pracy reaktora SBR [4]

Faza reakcji - w tej fazie wytwarzane są na przemian warunki tlenowe oraz niedotlenione. Obciążenie osadu czynnego rośnie wraz z ilością dopływających ścieków.

Faza sedymentacji - wstrzymana jest praca urządzenia napowietrzająco-mieszającego. Rozpoczyna się proces sedymentacji osadu oraz klarowania ścieków.

Faza dekantacji - po zakończeniu procesu sedymentacji osad czynny gromadzi się w warstwie przydennej, odsłaniając warstwę sklarowanych ścieków. Następuje pompowa lub statyczna dekantacja ścieków oczyszczonych. Po zakończeniu dekantacji usuwany jest osad nadmierny.

Faza martwa - to czas pomiędzy fazą dekantacji a napełnieniem. Potrzeba takiej fazy jest często konieczna, gdykilkareaktorów pracuje równolegle. Na tym etapie, w zależności od strategii eksploatacyjnej, może być stosowane mieszanie biomasy w celu kondycjonowania zawartości reaktywnej [3].

\section{WARIANTY TECHNOLOGII SBR}

\subsection{Cykliczny system osadów czynnych (CASS)}

Cykliczny system osadów czynnych (CASS) jest jednym z najpopularniejszych procesów reaktorów sekwencyjnych (SBR) stosowanych do oczyszczania ścieków komunalnych oraz ścieków z różnych branż, w tym rafinerii i zakładów petrochemicznych [5].

$\mathrm{W}$ porównaniu $\mathrm{z}$ tradycyjnym procesem osadu czynnego ma on wiele zalet eksploatacyjnych i wydajnościowych. Proces CASS SBR spełnia 
functions of a conventional sludge installation by using a single tank with variable volume in variable mode of operation, thus eliminating the requirement to use wastewater treatment and highly efficient pumping of activated sludge [1].

The Cyclic Activated Sludge System (CASS) combines a high level of process sophistication in a cost-effective, space-saving configuration that offers a methodology that is simple to use, flexible, reliable, not available in conventionally configured activated sludge systems. Its unique design provides an effective means to control sludge swelling, which is a common problem in conventional processes and other activated sludge systems [5].

The CASS SBR reactor tank is partitioned into three parts (zone 1 - selector, zone 2 - secondary aeration, zone 3 - main aeration) as shown in Figure 2. Sludge biomass is periodically recycled from Zone 3 to zone 1 to remove easily degradable soluble substrate and favouring the development of floccogenic microorganisms [5]. The design of the system shall be such that sludge return results in an approximate daily life cycle of the biomass in the main aeration zone through the selection zone. No special mixing devices or formal anaerobic mixing sequences are required to achieve the required discharge values. The configuration and operation mode of the tank enables the application of combined nitrogen and phosphorus removal mechanisms by means of a simple "onetime" aeration control [5].

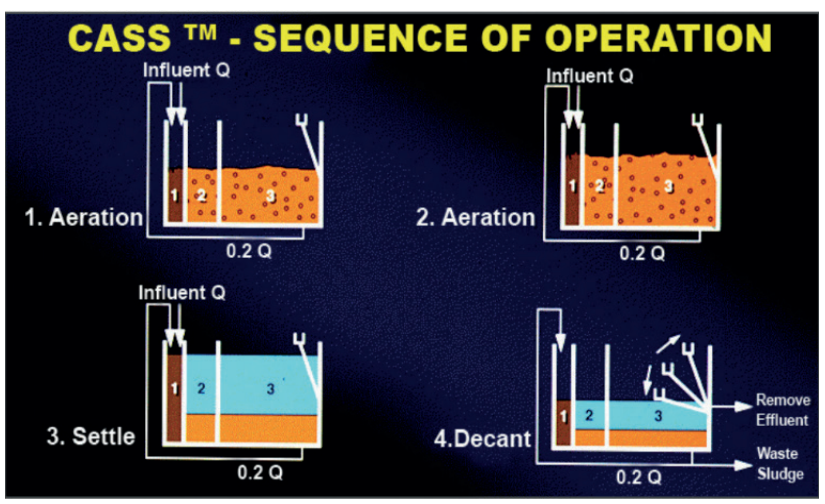

\subsubsection{Advantages of CASS}

SBR CASS maximizes ease of use, reliability and flexibility. Important reasons why CASS SBR is used compared to conventional aeration and treatment of fixed volume activated sludge include [6]:

- ability to work under continuous reduced load thanks to simple cycle adjustment; wszystkie funkcje konwencjonalnej instalacji osadu czynnego poprzez zastosowanie jednego zbiornika o zmiennej objętości w zmiennym trybie pracy, eliminując w ten sposób konieczność stosowania doczyszczania ścieków oraz wysokowydajnego pompowania osadu czynnego [1].

CASS łączy w sobie wysoki poziom zaawansowania procesu w konfiguracji, która jest ekonomiczna i zajmuje mało miejsca oraz oferuje metodologię, która jest prosta w obsłudze, elastyczna i niezawodna, niedostępna $\mathrm{w}$ konwencjonalnie konfigurowanych systemach osadu czynnego. Jego unikalna konstrukcja zapewnia skuteczne środki kontroli spęczniania osadu, co jest częstym problemem $\mathrm{w}$ konwencjonalnych procesach i innych systemach osadu czynnego [5].

Zbiornik reaktora CASS SBR podzielony jest przegrodowo na trzy części (strefa 1 - selektor, strefa 2 - napowietrzanie wtórne, strefa 3 - napowietrzanie główne), co jest przedstawione na rysunku 2. Biomasa osadowa jest okresowo poddawana recyrkulacji ze strefy 3 do strefy $1 \mathrm{w}$ celu usunięcia łatwo degradowalnego rozpuszczalnego substratu i sprzyjania rozwojowi mikroorganizmów flokotwórczych [5]. Nie są wymagane żadne specjalne urządzenia mieszające ani formalne beztlenowe sekwencje mieszania, aby osiągnąć wymagane wartości w zakresie odprowadzania ścieków. Konfiguracja i tryb pracy zbiornika umożliwia stosowanie połączonych mechanizmów usuwania azotu i fosforu poprzez prostą ,,jednorazową" kontrolę napowietrzania [5].

Fig. 2. The operating cycle of the CASS SBR reactor [5] Rys. 2. Cykl pracy reaktora CASS SBR (opracowanie własne na podstawie [5])

\subsubsection{Zalety CASS}

SBR CASS maksymalizuje prostotę obsługi, niezawodność i elastyczność. Do ważnych powodów, dla których CASS SBR jest stosowany w porównaniu $\mathrm{z}$ konwencjonalnym procesem napowietrzania i oczyszczania osadu czynnego o stałej objętości, można zaliczyć [6]:

- możliwość pracy pod ciągłym zmniejszonym obciążeniem dzięki prostej regulacji cyklu; 
- possibility of So/Xo operation (control of substrate/ microbial ratio), aeration intensity to prevent sludge swelling and ensure endogenous breathing (removal of all available substrates), nitrification and denitrification with increased phosphorus removal;

- possibility of working in conditions of simultaneous (co-current) nitrification and denitrification through variability of aeration intensity;

- highly tolerant of organic and hydraulic load variations. The system is easily configurable and operated in order to adapt to short-term and longterm seasonal changes;

- elimination of secondary settling;

- no separate load compensation. The SBR CASS container is itself an equalisation tank and a settling tank;

- the ability to remove nutrients without the addition of chemical compounds (calcium, PIX) by controlling the oxygen demand;

- capital benefits and low operating costs;

- effectively treats wastewater contaminated with oil;

- easy extension of the installation due to simple modular construction and common wall $[2,6]$.

\subsection{Unitank technology}

Unitank is a biological wastewater treatment system that combines the advantages of a traditional sludge process with those of an SBR reactor. The basic Unitank configuration consists of one tank divided into three hydraulically connected chambers [7]. The capacity of each chamber is the same, and it has an aeration system and there is no possibility of external recirculation of sludge. The outer compartments act alternately as aeration and sedimentary settling tanks and the central compartment as aeration units. A single operational cycle consists of two main stages. An advanced Unitank variant is used to remove nitrogen and phosphorus compounds. Wastewater is delivered to all three tanks, while after treatment it is collected from the central tank. This configuration has one or two additional anaerobic chambers with internal recirculation of mixed sludge [8]. Unitank is more suitable for small and medium sized wastewater treatment plants with the advantages of simple design, reduced space requirement, economical and reliable operation. Unitank is used in both square and round configurations, as shown in Figures 3 and 4. Unitank is most commonly used in countries such as China, Mexico, Argentina, Brazil, Vietnam and others [7].
- możliwość trybu pracy So/Xo (kontrola stosunku substratu do mikroorganizmów), intensywność napowietrzania w celu zapobiegania spęczniania się osadów i zapewnienia endogenicznego oddychania (usunięcie wszystkich dostępnych substratów), nitryfikacji i denitryfikacji wraz ze zwiększonym usuwaniem fosforu biologicznego;

- możliwość pracy w warunkach jednoczesnej (współprądowej) nitryfikacji i denitryfikacji poprzez zmienność natężenia napowietrzania;

- duża tolerancja na zmienność obciążenia organicznego i hydraulicznego. System jest łatwo konfigurowalny i obsługiwany w celu dostosowania do krótkotrwałych i długotrwałych zmian sezonowych;

- eliminacja osadnika wtórnego;

- eliminacja oddzielnego wyrównania obciążenia. Zbiornik SBR CASS jest sam w sobie zbiornikiem wyrównawczym i osadnikiem;

- zdolność do usuwania składników odżywczych bez dodatku związków chemicznych (wapno, PIX) poprzez kontrolę zapotrzebowania na tlen;

- niskie koszty inwestycyjne;

- skutecznie oczyszcza zanieczyszczenia olejami;

- łatwa rozbudowa instalacji dzięki prostej konstrukcji modułowej i ścianie wspólnej [2, 6].

\subsection{Technologia Unitank}

Unitank to biologiczny system, który łączy w sobie zalety tradycyjnego procesu $\mathrm{z}$ osadem czynnym oraz reaktora SBR. Podstawowa konfiguracja Unitank składa się z jednego zbiornika podzielonego na trzy seryjnie połączone hydraulicznie komory [7]. Pojemność komór jest jednakowa, posiada system napowietrzania i nie ma możliwości zewnętrznej recyrkulacji osadu. Przedziały zewnętrzne działają naprzemiennie jako osadniki napowietrzający i osadowy, natomiast środkowy jako jednostka napowietrzająca. Pojedynczy cykl składa się z dwóch głównych etapów. Do usunięcia związków azotu i fosforu stosuje się zaawansowany wariant Unitank, który wprowadza dodatkową komorę anoksyczną z wewnętrzną recyrkulacją wymieszanego osadu [8]. Ścieki doprowadzane są do wszystkich trzech zbiorników, natomiast po oczyszczeniu odbierane są z środkowej komory. Unitank jest bardziej odpowiedni dla małych i średnich oczyszczalni ścieków z zaletami prostej konstrukcji, mniejszego zajmowania terenu, oszczędnej i niezawodnej pracy. System Unitank jest stosowany zarówno w konfiguracjach prostokątnych, jak i okrągłych, co przedstawiają rysunki 3 oraz 4. Unitank najczęściej stosuje się w krajach takich jak: Chiny, Meksyk, Argentyna, Brazylia, Wietnam itp. [7]. 
Features of Unitank:

- advanced treatment to achieve stringent requirements for wastewater treatment;

- compact installation - easy to integrate anywhere;

- low noise and odour emissions;

- fully automatic, reliable and flexible operation;

- economical use of energy and chemicals;

- the basic concept for rapid design and construction;

- suitable for a wide range of wastewater types;

- favourable price/quality ratio $[1,8]$.
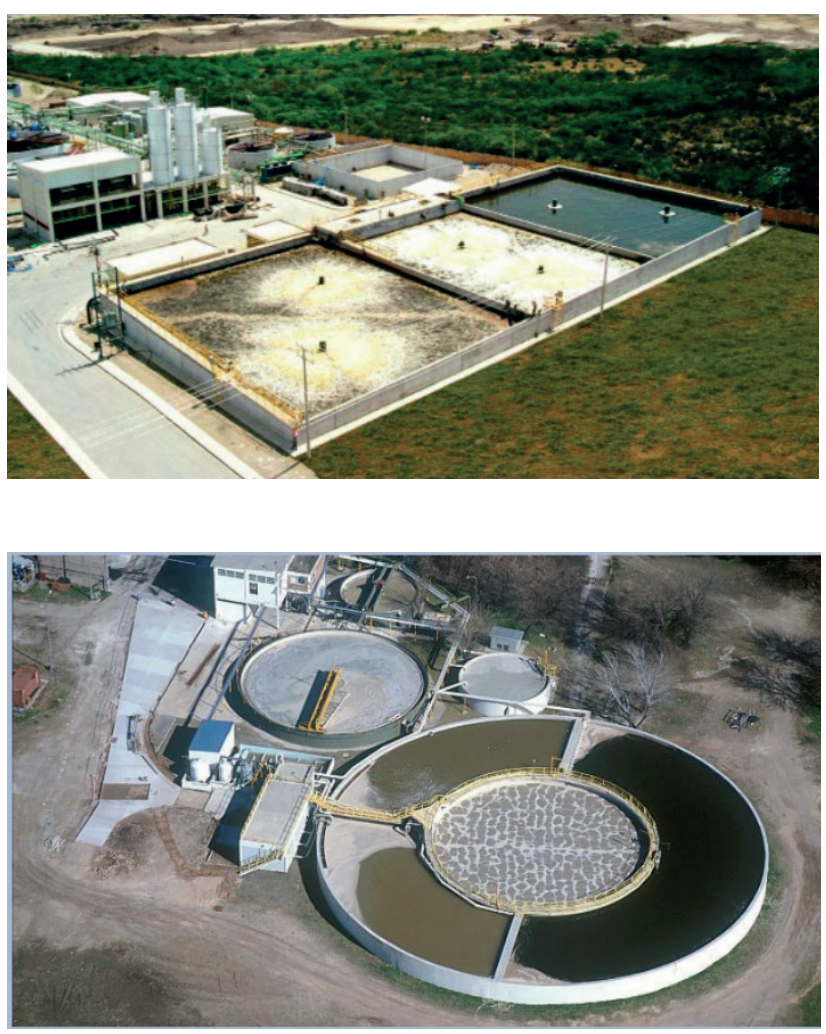

\subsection{Intermediate Extended Air System Cycle (ICEAS)}

A further improvement of the SBR batch technology is the ICEAS (Intermediate Cycle Extended Aeration System) process, which processes a continuous flow of wastewater. The variable flow is supported by a distribution box that distributes the flow evenly over all vessels to avoid overloading a single reactor. Prereaction zone with a high nutrient/microbial ratio acts as a selector. In this way, better sedimentation and flocculation inhibition can be achieved [4]. The main reactor zone, located in the pre-reaction zone, operates in three basic operating modes (reaction, sedimentation and decantation). Uniform loading of
Zalety systemu Unitank:

- zaawansowane oczyszczanie, spełniające surowe wymagania dotyczące oczyszczania ścieków;

- kompaktowa instalacja - łatwa do zintegrowania w każdym miejscu;

- niska emisja hałasu i odorów;

- w pełni zautomatyzowana, niezawodna i elastyczna obsługa;

- oszczędne zużycie energii i chemikaliów;

- podstawowa koncepcja, umożliwiająca szybkie projektowanie i budowę;

- przydatny do szerokiej gamy rodzajów ścieków;

- korzystny stosunek ceny do jakości $[1,8]$.

Fig. 3. Basic Unitank configuration in the square module. Pemex, Mexico, oil company [9]

Rys. 3. Konfiguracja Unitank podstawowa w module prostokatnym. Koncern naftowy Pemex, Meksyk [9]

Fig. 4. Unitank configurationin theroundmodule. Rousselot, Argentina [9]

Rys. 4. Konfiguracja Unitankwmoduleokragtym. Rousselot, Argentyna [9]

\subsection{Pośredni cykl rozszerzonego systemu napowietrzania (ICEAS)}

Kolejnym udoskonaleniem technologii wsadowego SBR jest proces ICEAS (Intermediate Cycle Extended Aeration System), który przetwarza ciągły dopływ ścieków. Zmienny dopływ jest obsługiwany przez skrzynkę rozdzielającą, która rozdziela przepływ równomiernie na wszystkie zbiorniki, aby uniknąć przeciążenia pojedynczego reaktora. Strefa przedreakcyjna o wysokim stosunku substancji odżywczych do mikroorganizmów F/M działa jak selektor. W ten sposób można osiągnąć lepsze osadzanie osadu i zahamowanie wzrostu kłaczków [4]. Główna strefa reaktora, znajdująca się po strefie przedreakcyjnej, działa w trzech 
all tanks with continuous inlet simplifies operation and control of the process. It also facilitates maintenance [10]. Compared to the conventional SBR process, the investment costs are much lower as only one set of tanks is required. ICEAS is becoming increasingly popular in China, USA, UK, Peru, Qatar, etc. due to the replacement of old wastewater treatment plants or the construction of new plants with limited space or better wastewater quality requirements [11]. Figure 5 shows a schematic representation of the ICEAS process cycle.

ICEAS Operating Cycle

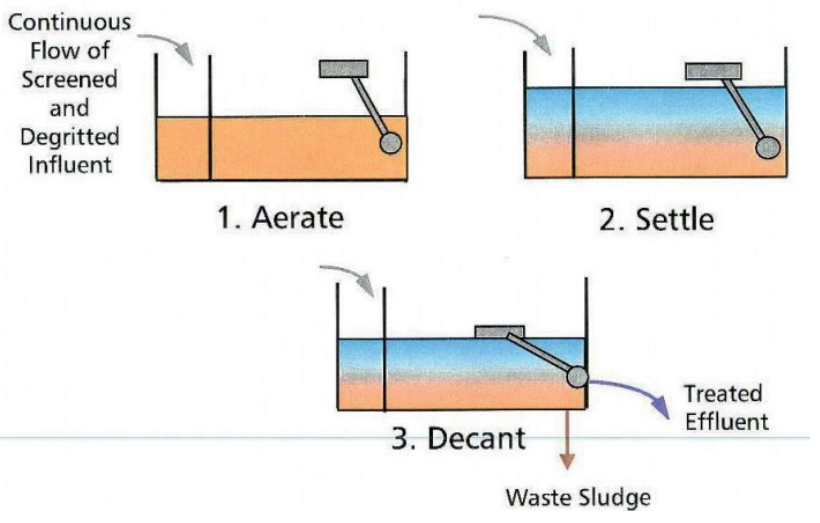

Advantages of ICEAS:

- capacities from $100 \mathrm{~m}^{3} / \mathrm{d}$ to $300.000 \mathrm{~m}^{3} / \mathrm{d}$ with the possibility of handling large flow fluctuations;

- minimises energy consumption by up to $50 \%$;

- there is little usable floor space;

- simple, intuitive control;

- removes nitrogen and phosphorus;

- capable of acting as a single container to facilitate maintenance and/or to provide shutdown if the system is operated below design loads [10].

\section{PROCESS CONTROL}

The SBR process outperforms the activated sludge processes due to its superiority in many respects, such as improved COD quality in wastewater, better control of filamentous bacteria and low energy consumption. These achievements were made possible by the excellent process control in the SBR. SBR process control technologies have evolved steadily over the past 30 years, leading to the development of a wide range of control systems to balance the complexity of the SBR process [2]. podstawowych trybach pracy (reakcji, osadzania oraz dekantacji). Równomierny załadunek wszystkich zbiorników przy ciągłym dopływie upraszcza obsługę i kontrolę procesu. Ułatwia również konserwację [10]. $\mathrm{W}$ porównaniu z konwencjonalnym procesem SBR koszty inwestycyjne są znacznie niższe, ponieważ wymagany jest tylko jeden zestaw zbiorników. ICEAS cieszy się coraz większą popularnością w Chinach, USA, Wielkiej Brytanii, Peru, Katarze itp. ze względu na zastępowanie starych oczyszczalni ścieków lub budowę nowych zakładów, w których dostępna jest ograniczona przestrzeń lub wymagana jest lepsza jakość ścieków [11]. Rysunek 5 przedstawia schematycznie cykl działania procesu ICEAS.

Fig. 5. ICEAS operation diagram [12]

Rys. 5. Schemat działania układu ICEAS [12]

Zalety układu ICEAS:

- wydajności od $100 \mathrm{~m}^{3} / \mathrm{d}$ do $300,000 \mathrm{~m}^{3} / \mathrm{d} \mathrm{z}$ możliwością obsługi dużych wahań przepływu;

- minimalizuje zużycie energii nawet o $50 \%$;

- niewielka powierzchnia użytkowa;

- proste, intuicyjne sterowanie;

- skutecznie usuwa azot i fosfor;

- zdolność do działania w charakterze pojedynczego zbiornika w celu ułatwienia konserwacji i/lub zapewnienia wyłączenia, jeżeli instalacja pracuje poniżej obciążeń projektowych [10].

\section{KONTROLA PROCESU}

Proces SBR przewyższa proces osadu czynnego w wielu aspektach, takich jak lepsza jakość ścieków pod względem ChZT, lepsza kontrola bakterii nitkowatych oraz niskie zużycie energii. Osiągnięcia te były możliwe dzięki doskonałej kontroli procesu w SBR. W ciągu ostatnich 30 lat technologie sterowania procesem SBR stale się rozwijały, prowadząc do opracowania szerokiej gamy systemów sterowania, aby zrównoważyć złożoność procesu SBR [2]. 
The classic SBR control is performed with a fixed time cycle, which has the disadvantage that it does not allow the length cycle to be adjusted to compensate for the effect of process deviations and changes in the composition of the delivered wastewater. On the other hand, real-time control should provide greater flexibility to adjust the optimized control under different conditions [13]. Precise process control in real time requires feedback at least at the beginning and the end of the different biological reactions within the SBR. Real-time monitoring of direct parameters such as COD or BOD and various forms of nitrates and phosphates may not be sufficiently accurate with currently available technology [14]. Monitoring of parameters, such as $\mathrm{pH}$, dissolved oxygen and redox potential, may successfully indicate reaction processes that occur during carbon and nitrogen removal in SBR processes [13]. Figure 6 shows the time dependence of these parameters during one typical conventional SBR cycle, as well as the concentration values of $\mathrm{COD}$ and various forms of nitrogen.

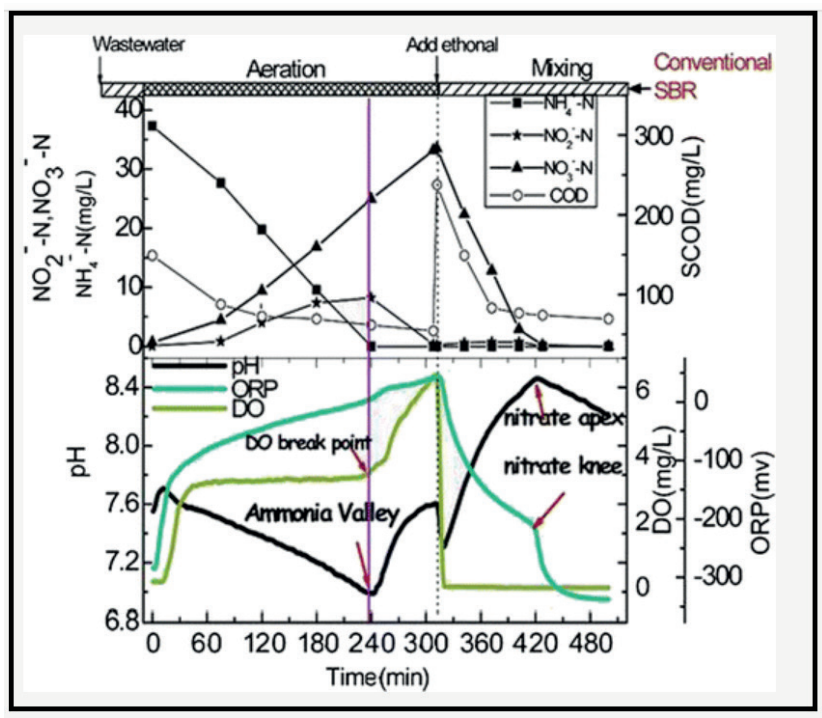

The redox potential is directly related to the nitrification rate and other biological reactions under aerobic or anaerobic conditions [13]. Under normal conditions, the redox potential is positive and increases in the aeration phase, and negative in the anaerobic phase. The normal range of redox potentials is from $0 \mathrm{mV}$ to $50 \mathrm{mV}$ under aerobic conditions and from $0 \mathrm{mV}$ to $-300 \mathrm{mV}$ under anaerobic conditions. In the anaerobic phase, the redox potential decreases with time; there is a steep slope, known as the nitrate knee, which signifies the end of denitrification, so
Klasyczną kontrolę SBR przeprowadza się przy ustalonym cyklu czasowym, co ma tę wadę, że nie pozwala na dostosowanie cyklu długości w celu skompensowania wpływu odchyleń procesu i zmian w składzie dostarczanych ścieków. Z drugiej strony, sterowanie w czasie rzeczywistym powinno zapewnić większą elastyczność w celu dostosowania zoptymalizowanego sterowania w różnych warunkach [13]. Precyzyjna kontrola procesu w czasie rzeczywistym wymaga informacji zwrotnej przynajmniej na temat początku i końca różnych reakcji biologicznych zachodzących w ramach SBR. Monitorowanie w czasie rzeczywistym bezpośrednich parametrów, takich jak ChZT lub BZT, oraz różnych form azotanów i fosforanów może nie być wystarczająco dokładne przy obecnie dostępnej technologii [14]. Monitorowanie parametrów takich jak $\mathrm{pH}$, tlen rozpuszczony oraz potencjał redoks może dostarczać informacji na temat reakcji, które zachodzą podczas usuwania węgla i azotu w procesach SBR [13]. Na rysunku 6 przedstawiono zależności tych parametrów od czasu podczas jednego typowego cyklu układu SBR, a także wartości stężenia ChZT oraz różnych form azotu.

Fig. 6. Curves of dissolved oxygen values, $\mathrm{pH}$, redox potential and $\mathrm{NH}_{4}-\mathrm{N}, \mathrm{NO}_{2}-\mathrm{N}$ and $\mathrm{NO}_{3}-\mathrm{N}$ concentrations during the nitrification and denitrification process in the $S B R$ reactor [13]

Rys. 6. Krzywe wartości tlenu rozpuszczonego, $p H$, potencjatu redoks oraz stężeń $\mathrm{NH}_{4}-\mathrm{N}, \mathrm{NO}_{2}-\mathrm{N}$ i $\mathrm{NO}_{3}-\mathrm{N}$ podczas procesu nitryfikacji $i$ denitryfikacji $w$ reaktorze SBR (opracowanie własne na podstawie [13])

Potencjał redoks wykazuje bezpośredni związek z szybkością nitryfikacji i innymi reakcjami biologicznymi w warunkach tlenowych lub beztlenowych [13]. W normalnych warunkach potencjał redoks jest dodatni i wzrasta w fazie napowietrzania, a ujemny w fazie beztlenowej. Normalny zakres wartości potencjału redoks wynosi od $0 \mathrm{mV}$ do $50 \mathrm{mV}$ w warunkach tlenowych oraz od $0 \mathrm{mV}$ do $-300 \mathrm{mV}$ w warunkach beztlenowych. W fazie beztlenowej potencjał redoks maleje w zależności od czasu; występuje strome opadanie, znane jako kolano azotanowe, które oznacza koniec 
that the anaerobic phase can be safely stopped and the next step started [15].

During denitrification, the $\mathrm{pH}$ increases and decreases during the nitrification process [13]. There are two important points on the $\mathrm{pH}$-value curve with respect to time:

1. Ammonia valley. As ammonia is oxidised to nitric acid in the first phase of nitrification, the $\mathrm{pH}$ gradually decreases at the beginning of the process. When all the ammonia is oxidised to produce a peak concentration of nitrites, the acid production process is stopped, the $\mathrm{pH}$ curve reaches a minimum value, which is referred to as the "ammonia valley" [15].

2. Nitrate apax. During the anaerobic phase, the $\mathrm{pH}$ increases and forms a steadily increasing graph. Maximum achievement is achieved when all nitrate is converted to nitrogen, indicating the end of the denitrification phase. The "tip of nitrate" exactly corresponds to the "nitrate knee" as observed in the redox potential value curve [15].

Studies show that the $\mathrm{pH}$ profile is the best indicator of changes in the value of microorganisms occurring inside the SBR reactor [13]. However, the overall alkalinity of waste water often provides a significant buffering capacity which minimizes noticeable fluctuations in $\mathrm{pH}$ which reduces the $\mathrm{pH}$ value as an indicator [15].

During aeration, when COD is reduced, dissolved oxygen is consumed. In the case of nitrification, which takes place in two stages, the oxygen consumption in the first stage of the process is three times higher than in the second stage. In the second stage of the process, the level of dissolved oxygen increases noticeably. The point where the nitrification process steps change occurs at the same time as the "ammonia valley" [14]. After aeration, the oxygen value drops rapidly to zero and keeps it until the end of the anaerobic phase.

Oxygen controls (OUR) are becoming more and more popular. OUR is the consumption of oxygen in a time unit per reactor volume unit, which can be calculated by a PC or PLC (Programmable Logic Controller) from oxygen sensor-based measurements. OUR was used to control new SBR processes such as short-chain nitrification and intensification of biological phosphorus removal (EBPR). The point of refraction of the OUR signal curve (the first OUR derivative), from negative to positive, indicated the end point of phosphate uptake [16]. denitryfikacji, dzięki czemu można bezpiecznie zatrzymać fazę beztlenową i rozpocząć kolejny etap [15].

Podczas denitryfikacji pH wzrasta i spada podczas procesu nitryfikacji [13]. Istnieją dwa ważne punkty na krzywej wartości pH w odniesieniu do czasu:

1. Dolina amoniaku. Ponieważ w pierwszej fazie nityryfikacji amoniak jest utleniany do kwasu azotowego(III), $\mathrm{pH}$ na początku procesu ulega stopniowemu obniżeniu. Gdy cały amoniak zostanie utleniony w celu wytworzenia szczytowego stężenia azotynów, następuje zatrzymanie procesu wytwarzania kwasu, krzywa pH osiąga minimalną wartość, która określa się jako „dolina amoniaku” [15].

2. Wierzchołek azotanowy. Podczas fazy beztlenowej pH wzrasta. Maksimum osiąga się, gdy cały depozyt jonów azotanowych zostaje przekształcony w azot, wskazując koniec fazy denitryfikacji. „Wierzchołek azotanowy” dokładnie odpowiada „kolanowi azotanowemu”, co zaobserwowano na krzywej wartości potencjału redoks [15].

Badania pokazują, że profil $\mathrm{pH}$ jest najlepszym wskaźnikiem zmian liczebności mikroorganizmów zachodzących wewnątrz reaktora SBR [13]. Jednakże zasadowość ogólna ścieków często zapewnia znaczną zdolność buforowania, która minimalizuje zauważalne wahania $\mathrm{pH}$, co zmniejsza wartość $\mathrm{pH}$ jako wskaźnika [15].

Podczas napowietrzania, gdy ChZT ulega obniżeniu, zużywa się tlen rozpuszczony. W przypadku nitryfikacji, która zachodzi dwuetapowo, zużycie tlenu $\mathrm{w}$ pierwszym etapie procesu jest trzykrotnie większe niż w drugim. W drugim etapie procesu poziom tlenu rozpuszczonego zauważalnie rośnie. Punkt zmiany etapów procesu nitryfikacji następuje w tym samym czasie co „dolina amoniaku” [14]. Po zakończeniu napowietrzania wartość tlenu gwałtownie spada do zera i utrzymuje go do końca fazy beztlenowej.

$\mathrm{Z}$ racji prostej obsługi i dokładności pomiarów coraz popularniejsze stają się kontrole poboru tlenu (OUR). OUR jest to zużycie tlenu w jednostce czasu na jednostkę objętości reaktora, które może być obliczone przez komputer PC lub sterownik PLC (programowalny sterownik logiczny) na podstawie pomiarów tlenu opartych na czujnikach. OUR zastosowano w kontroli nowych procesów SBR, takich jak nitryfikacja krótkołańcuchowa oraz intensyfikacja biologicznego usuwania fosforu (EBPR). Punkt załamania krzywej sygnału dOUR (pierwsza pochodna OUR), od ujemnej do dodatniej, wskazywał punkt końcowy pobierania fosforanu [16]. 
At the end of the twentieth century, mathematical modelling became popular to optimise performance and effectively control contaminant removal in SBR by simulation, instead of experimenting with trials and errors on a full scale. Model IAWQ ASM2 with further modifications can be used for modelling of long-term nutrient removal in SBR with better phosphorus dynamics [16].

\section{CONCLUSIONS}

The use of various variants of SBR reactor improvements allows for better treatment of wastewater depending on the requirements of a given treatment plant. In case of problems with swelling sludge and high variability in the amount of incoming wastewater, it is beneficial to introduce the CASS system, which additionally does not require a large area for expansion. Another solution is Unitank technology, which is ideal for smaller plants with a high diversity of inflowing wastewater. However, in order for the system to effectively treat wastewater with high nitrogen and phosphorus content, additional anaerobic chambers must be introduced. The most recent configuration presented is the ICEAS system, which has an unquestionable advantage of up to $300.000 \mathrm{~m}^{3} / \mathrm{d}$ with the possibility of handling large flow fluctuations. It is very popular due to lower investment costs as well as energy savings of up to $50 \%$ compared to the classical system. The main disadvantage of SBR reactors is the cyclical removal of daily sewage load, which makes the system sensitive to daily and hourly irregularity in the sewage inflow.

However, in order to correctly estimate which modernization is most beneficial for a given plant, simulation models are used, with the latest and most popular being the IAWQ ASM2 model. It allows, among other things, to simulate the operation of the plant after each of the available upgrades and to select the most efficient one.

Modelling programs also allow advanced process control, which is at the heart of the SBR system. The introduction of a real-time control strategy can enable the SBR process to achieve greater robustness, reliability and optimized performance. This will increase energy efficiency and help widen the scope of the SBR process. Future research on SBR strategies should include the development of an intelligent monitoring system that evaluates feedback in real time. In this way, the SBR process adapts to changing environmental conditions and the changing quality of
Pod koniec XX wieku popularne stało się modelowanie matematyczne $\mathrm{w}$ celu optymalizacji działania i skutecznej kontroli usuwania zanieczyszczeń w SBR poprzez symulację zamiast przeprowadzania eksperymentów metodą prób i błędów na pełną skalę. Obecnie często stosowany jest model do symulacji reaktora SBR, tj. model IAWQ ASM2. Model pozwala na przeprowadzenie symulacji pracy oczyszczalni pod wpływem parametrów znacznie odbiegających od normy, pozwala również na przewidywanie skutków ewentualnej awarii oraz na przetestowanie korzyści płynących z modernizacji oczyszczalni. Może on być skutecznie wykorzystany do modelowania długoterminowego usuwania składników pokarmowych w SBR z uwzględnieniem szerokiej dynamiki zmian stężenia fosforu [16].

\section{WNIOSKI}

Zastosowanie różnych wariantów usprawnień reaktorów SBR pozwala na lepsze oczyszczanie ścieków w zależności od potrzeb danej oczyszczalni. W przypadku problemów z pęczniejącym osadem oraz dużych zmienności w ilości dopływających ścieków korzystne jest wprowadzenie układu CASS, który dodatkowo nie wymaga dużej powierzchni w ramach rozbudowy. Kolejną propozycją jest technologia Unitank, sprawdzająca się idealnie w mniejszych oczyszczalniach o wysokiej różnorodności ścieków dopływających. Jednakże aby układ skutecznie oczyszczał ścieki z wysoką zawartością azotu i fosforu, należy wprowadzić dodatkowe komory beztlenowe. Ostatnią przedstawioną konfiguracją jest układ ICEAS, którego niewątpliwą zaletą jest wydajność do $300000 \mathrm{~m}^{3} / \mathrm{d}$ z możliwością obsługi dużych wahań przepływu. Cieszy się on dużą popularnością ze względu na niższe koszty inwestycyjne, jak również oszczędność zużycia energii nawet do $50 \% \mathrm{w}$ stosunku do klasycznego układu. Główną wadą reaktorów SBR jest cykliczny zrzut dobowego ładunku ścieków, przez co układ jest wrażliwy na nierównomierność dobową i godzinową w dopływie ścieków.

Jednakże aby poprawnie oszacować, jaka modernizacja jest najbardziej korzystna dla danej oczyszczalni, stosuje się modele do symulacji, przy czym najnowszym i najbardziej popularnym jest model IAWQ ASM2. Pozwala on między innymi na przeprowadzenie symulacji działania pracy oczyszczalni po każdej z dostępnych modernizacji i wybraniu najbardziej efektywnej.

Programy do modelowania pozwalają również na zaawansowaną kontrolę procesu, która jest sercem układu SBR. Wprowadzenie strategii sterowania 
waste water in order to maintain optimal quality of treated waste water while maintaining a high degree of reliability. w czasie rzeczywistym może umożliwić procesowi SBR osiągnięcie większej solidności, niezawodności i zoptymalizowanej pracy. Zwiększy to efektywność energetyczną i pomoże poszerzyć zakres stosowania procesu SBR. Przyszłe badania nad strategiami systemu SBR powinny obejmować opracowanie inteligentnego systemu nadzoru, który w czasie rzeczywistym dokonuje ewaluacji informacji zwrotnych. W ten sposób proces SBR dostosowuje się do zmieniających się warunków środowiskowych oraz do zmieniającej się jakości ścieków, tak aby utrzymać optymalną jakość ścieków oczyszczonych przy zachowaniu wysokiego stopnia niezawodności.

\section{REFERENCES}

[1] Mittal A., Biological Wastewater Treatment, "Water Today", August 2011, pp. 32-41.

[2] Metcalf \& Eddy Inc., Tchobanoglous G., Burton F.L., Stensel H.D., Wastewater Engineering: Treatment and Reuse, 4th edition, Chicago 2003.

[3] Heidrich Z., Witkowski A., Urządzenia do oczyszczania ścieków, Seidel-Przywecki, Warszawa 2005.

[4] Masłoń A., Tomaszek J., Sekwencyjne reaktory porcjowe w oczyszczaniu ścieków, Politechnika Rzeszowska, 2011.

[5] <https://www.chemtech-online.com/WAT/Arun july11.html> [dostęp: 12.06.2018>.

[6] <http://www.watertoday.org/Article\%20Archieve/Aquatech\%2012.pdf> [dostęp: 16.06.2018].

[7] Zhang F., Liu J., Sui J., Sludge concentration dynamic distribution and its impact on the performance of UNITANK, "Journal of Environmental Sciences" 2007, 19, s. 141-147.

[8] Bao D.J., Liu Z.M., Li J., Research on UNITANK technology and its application in municipal wastewater treatment plant, Appl. Mech. Mater., 2013.

[9] <www.keppelseghers.com/en/download.ashx?id=2728> [dostęp: 13.06.2018].

[10] <https://www.xylem.com/en-us/products-services/treatment-products-systems/biological-treatment-processes/ sequential-batch-reactor-sbr/iceas-advanced-sbr-d3f8bba3> [dostęp: 12.06.2018].

[11] <https://www.xylem.com/Assets/Resources/1710-Sanitatire-ICEAS-BiologicalTreatmentProcess.pdf> [dostęp: 11.06.2018].

[12] <http://www.ohiowea.org/docs/Sanitaire_Pemberville_Presentation.pdf> [dostęp: 13.06.2018].

[13] Dutta A., Sarka S., Sequencing Batch Reactor for Wastewater Treatment: Recent Advances, "Water Pollution" 2015, Vol. 1, Issue 3, pp. 177-190.

[14] Blackburne R., Yuan ZQ., Keller J., Demonstration of nitrogen removal via nitrite in a sequencing batch reactor treating domestic wastewater, Water Res., 2008.

[15] Peng Y.Z., Shao-Po W., Shu-Ying W., Jian-Ge H., Hai-Bing Q., Effect of denitrification type on pH profiles in the sequencing batch reactor proces, Water Sci. Technol., 2006.

[16] Yang Q., Gu S., Peng Y., Wang S., Liu X., Progress in development of control strategies for the SBR proces, “CleanSoil Air Water" 2010.

\section{Acknowledgments:}

The work was financed by the Kielce University of Technology, part of the statutory work No. 05.0.00.00/2.01.01.01.0001 MNSP.I.19.001

\section{Podziękowania:}

Praca była finansowana przez Politechnikę Świętokrzyska, $w$ ramach pracy statutowej $n r:$ 05.0.00.00/2.01.01.01.0001 MNSP.I.19.001 